\title{
LA SOGIOLOGÍA LITERARIA DE DON FRANCÉS DE ZÚÑIGA
}

\section{DON FrancÉS, UN NUEVO RICO}

Señalaba M. Foucault que a finales de la Edad Media existía un espacio moral de exclusión de la sociedad, en el que se mezclaban leprosos, enfermos venéreos, locos, pobres, necesitados, homosexuales, haraganes, mentirosos, borrachos, mendigos, impúdicos, etc. ${ }^{1}$ El Renacimiento (y más concretamente la Iglesia y la creciente burguesía) se encargaría de relajar poco a poco esta exclusión. Algunos de esos grupos marginales comenzaron a tener un trato más favorable, o incluso alcanzaron la integración o la rehabilitación de algunos de sus miembros, que llegaron a conseguir un status social de aceptación dentro de los márgenes oficiales de la sociedad establecida.

Salir del ghetto era algo que atañía no sólo a los grupos marginales sino también a la capas más bajas de aquella jerarquía social, a las que pertenecían los plebeyos y los menestrales. Si los primeros (los marginados) tendían hacia la integración, los segundos aspiraban a mejorar su calidad social, es decir, a subir uno o más peldaños en la escalera jerárquica.

La desigualdad, como señalara A. Domínguez Ortiz, “era un hecho universalmente aceptado" "2. Ciertamente, pero la aceptación de esa desigualdad no entrañaba un conformismo tal como el que había existido en las épocas precedentes entre los estratos medios y bajos de la sociedad. En España, los Reyes Católicos 86-91

1 Historia de la locura en la época clásica, F.C.E., México, 1979, t. 1, pp.

2 El antiguo régimen: los Reyes Católicos y los Austrias, t. 2 de La historia de España, Alianza-Alfaguara, Madrid, 1973, p. 108. 
habían delimitado las fronteras de la nobleza con las leyes de Córdoba (1492), pero al mismo tiempo facilitaron a los nuevos ricos la forma de traspasar dichas fronteras mediante las leyes de Toro (1505), que regulaban los mayorazgos, con los cuales ponían al alcance de la burguesía una situación casi nobiliaria ${ }^{3}$. De esta forma, continúa A. Domínguez Ortiz, "las utopías sociales sólo podían ser fruto de algún pensador aislado. Entonces, el camino que se ofrecía al ambicioso, al descontento, no era el de procurar el derrocamiento del sistema, sino tratar de buscar mejor acomodo dentro de él. [...] En la práctica, el favor, la habilidad y sobre todo la riqueza abrían un camino hacia arriba"' 4 . La movilidad social, en su sentido vertical, es un hecho que se constata con la aparición, a fines del siglo XV, de grupos de nuevos ricos que van a la zaga de las economías españolas más señoriales ${ }^{5}$.

La biografía del bufón don Francés de Zúñiga muestra que éste fue, en toda su extensión, un nuevo rico; un homo novus que partió de la nada hasta lograr, en los últimos años de su vida, "mi persona y casa tener autoridad", como notificara él mismo en una carta al emperador ${ }^{6}$. Contemplando la construcción de su vida, hoy diríamos que fue un self-made man: un desheredado que triunfa en la vida.

Nacido en Béjar hacia $1480^{7}$, el primer hecho que determina

3 Ibid., pp. 14-17.

4 Ibid, p. 108.

5 Cf: J. A. Maravall, "La época del Renacimiento", en Pedro Laín ENTRALGO, Historia universal de la medicina, Salvat, Barcelona, 1975, t. 4, pp. 1-19.

6 "Epistolario del mismo famoso coronista don Francés", A. de Castro (ed.), Curiosidades bibliográficas, BAE, Madrid, 1855, t. 36, p. 61b. Siempre que se cite el epistolario en este trabajo se hará por esta edición, única existente, por lo que en cada caso se consignarán exclusivamente las páginas correspondientes.

7 Poco y mal es lo que se ha conjeturado sobre el lugar y la fecha de nacimiento de nuestro autor. En cuanto a la fecha, sólo Diane Pamp de AvalleArce en su ed. de la Crónica burlesca del emperador Carlos V, de FRANCEsillo DE ZÚÑIGA, Crítica, Barcelona, 1981, p. 38, se había aventurado hasta ahora a proponer la de 1490; el descubrimiento por mi parte de determinados datos relativos a sus descendientes (Don Francés de Zúniga. Biografría y algunos aspectos de sus obras, tesis de licenciatura, Universidad de Salamanca, 1984, pp. 25-31) me permiten retraerla en diez años a la propuesta por Pamp. Por lo que respecta al lugar, ocasionalmente se había indicado para el bufón un origen navarro, la villa abulense de Navarredonda de la Sierra o la salmantina de Navarredonda de la Rinconada, pero ya A. González Palencia ("El mayorazgo de don Francés de Zúñiga", Del "Lazarillo" a Quevedo, C.S.I.C., Madrid, 1946, pp. 42-51), había apuntado hacia la entonces villa y hoy ciudad de Béjar (Salamanca) como el lugar donde nace y muere don Francés, hecho 
la vida del bufón es su condición de judío converso ${ }^{8}$. Su origen es notoriamente humilde ("de cepa no ya humilde, sino también roñosa", le llega a calificar con extremo don Juan Menéndez Pidal). Desconocemos el oficio y la hacienda dal padre, pero es sabido que el futuro bufón ejerció en su juventud en Béjar la profesión de sastre, en la cual eran diestros y señalados los de su raza ${ }^{9}$. Hacia 1505 se casa, y no muchos años después entra al servicio del duque de Béjar, don Álvaro de Zúñiga, uno de los más destacados personajes de la nobleza y de la corte española del momento ${ }^{10}$. Es su primer ascenso cualitativo: de sastre pasa a ser hombre de placer del duque; de la sastrería, al palacio ducal; del trato con sus iguales, al trato con los duques bejaranos. Y lo que también es importante, desde un punto de vista literario: con sus (seguramente) " escasas letras", entra a la biblioteca del palacio ducal de su amo, una de las mejores en su tiempo, según los indicios que de ella se tienen ${ }^{11}$.

Un segundo ascenso, que podríamos considerar intermedio, es su paso, ya como bufón a la corte. Esto lo realiza al acompañar al duque de Béjar, con quien compartió más de una estancia durante el período que va desde que entró a su servicio hasta 1522 . Tenemos ya a don Francés en el ámbito de la cortesanía, que sería tan fundamental en su obra.

Sin duda podría considerarse, para un hombre de su bajo origen y procedencia, como máximo logro de su fortuna y ascenso la entrada al servicio real: en 1522 Carlos $\bar{V}$ le toma como bu-

que se puede casi deducir de las referencias que de sus orígenes se tienen, de su dependencia del duque de Béjar (de quien lleva incluso el apellido) y de los últimos años de su vida, en los que es nombrado alguacil de la villa bejarana y donde muere.

8 Véase Juan Menéndez Pidal, "Don Francesillo de Zúñiga, bufón de Carlos V. Cartas inéditas", RABM, 20 (1909), 182-199 (concretamente las pp. 185-186) y D. PAMP, op. cit., pp. 39-41.

9 J. Caro Baroja, Los judíos en la España moderna y contemporánea, Istmo, Madrid, 1978, t. 2, p. 15.

10 Don Francés de Zúniga. Biografía..., pp. 26 ss.

11 "Según investigaciones del conspicuo Paz y Meliá, la mejor biblioteca de su época en España. Libros valiosos, códices importantes y raros ornados de exquisitas miniaturas, ejemplares representativos de las culturas griega, latina, italiana, española y provenzal [...] constituyeron el inmenso tesoro bibliográfico que guardaban los muros del Palacio de Béjar", P. Vicente Rubio, O. P., Las letras españolas y Béjar, Establecimiento tipográfico S. Urrea, Béjar, 1960, p. 7. Puede verse también A. Redondo, "La bibliothèque de don Francisco de Zúñiga, Guzmán y Sotomayor, troisième duc de Béjar (1500-1544)"', MCV, 3 (1967), 147-196. 
fón personal y de la corte. Para muchos como él, no podía caber mayor aspiración que la de ser un servidor regio. Un refrán de la época indicaba cuáles eran los caminos que tenía el español de baja cuna para hacer fortuna: "Tres cosas hacen al hombre medrar: Iglesia y mar y Casa Real"'12. Muchos buscaban oficio en la corte, pero pocos lo conseguían. El propio don Francés da cuenta de la situación: “. ...y no andar como ando, flaco y trasijado, siguiendo el palacio, con una voluntad de ser aprovechado, como otros quinientos amigos míos, y criados de vuestra majestad"' (61 b).

A alguien salido de una sastrería para ser criado de un poderoso (el duque de Béjar), podía parecerle la cúspide de toda fortuna alcanzar un oficio en la mismísima Casa Real. Pero en distintos lugares de su Espistolario, el escritor bejarano se muestra descontento con su posición. En 1526 solicita al emperador que le provea de un oficio de escribano, que aquél le miega ${ }^{13}$; en otros momentos, entre burlas y veras, le solicita ciertas rentas eclesiásticas $(61 b)$. ¿Dónde paraba la aspiración social del reticente bufón?

Ciertamente, su posición cortesana no fue tan favorable como se presenta en apariencia. A nuestros ojos puede parecer que no cabía mayor medro personal que estar junto al emperador, pero el propio don Francés manifiesta que andaba "siguiendo el palacio, con voluntad de ser aprovechado". Lo mismo que Francisco López de Villalobos, lo mismo que Antonio de Guevara, tan próximos vital y literariamente a él, sentía como ellos una misma relación contradictoria de amor y odio hacia la corte. Ésta les daba el prestigio y la posición social que su cuna les había negado, pero también les proporcionaba los desasosiegos de su impotencia por no pertenecer de derecho al mundo al cual estaban adscritos de hecho. De los tres, seguramente fue don Francés de Zúñiga el que más clara conciencia tuvo de no ser un cortesano de ley, y también el de peor posición económica. Para J. MorenoVilla, hombres del tipo de nuestro bufón eran criados anormales. Refiriéndose a los locos y enanos de la corte de los Austrias, dice: "Si tales sujetos hubieran sido criados normales, con oficio, cargo o misión determinada, hubiera bastado con recurrir a las nóminas o a los asientos o pagos de medias anatas. Pero da la casualidad de que el ser enano o loco no es mi oficio ni cargo; nadie puede ser nombrado loco o enano en tal día de tal año. Además, no todos

12 Felipe C. R. Maldonado, Refranero clásico español, Taurus, Madrid, 1981, p. 177.

$13 \mathrm{~J}$. Menéndez Pidal, art. cit, p. 77. 
eran remunerados por la misma oficina. Unos cobraban en raciones de cera, o sea por la Cerería; otros cobraban en panes, por la Panadería; unos son pagados simplemente con mercedes de vestidos; otros no figuran más que en los viajes o jornadas..." ${ }_{14}$

Con este valioso dato comprendemos un poco mejor el afán de don Francés de buscarse un oficio mejor o ingresos más seguros. Con esta luz se entiende que aunque se encontrase en una supuesta cúspide de la fortuna, no estuviera satisfecho de su posición cortesana. No se sale del ghetto simplemente para apaciguar la autoestimación: se sale para alcanzar una posición social económicamente mejorada. $\mathrm{O}$ al menos que acompañe el nivel de autoestimación.

De todas formas, don Francés no tenía las espaldas descubiertas. Aproximadamente por las mismas fechas en que entraba al servicio del emperador, éste le concedió facultad para fundar mayorazgo ${ }^{15}$. Desconocemos qué bienes pudo tener el bufón en aquel momento o en años posteriores. Existe una levísima referencia a su situación económica en el Espejo del Príncipe Christiano de Francisco de Monzón, quien dice que Carlos V "tenía un truhán llamado Francés, gran privado y amigo suyo, a quien por sus gracias había enriquecido" "Hasta qué punto podemos fiarnos de esta afirmación de Monzón, es algo que no podemos dilucidar en este momento. Puede ser enteramente cierto ese enriquecimiento, o puede ser parte de la aureola que rodeó su figura en los años posteriores a su muerte, y que le hizo protagonista de hechos $y$ anécdotas que en forma alguna le son imputables ${ }^{17}$. Al perder el favor real en 1529 y retirarse de la corte, regresó a vivir a Béjar. Meses después escribió una carta a la emperatriz en la que por dos veces se refiere a " $m i$ villa de Navarredonda"'18. Ese posesivo con el que don Francés habla de Na-

$14 \mathrm{~J}$. Moreno VilLA, Locos, enanos, negros y niños palaciegos en la corte espanola de los Austrias, La Casa de España en México, 1939, p. 16. Más adelante en este mismo trabajo veremos que aunque el ser loco no sea ni oficio ni cargo, indudablemente sí representa una importante función estructural dentro de la corte.

15 Véase A. González Palencia, art. cit. La fecha del otorgamiento fue el 21 de octubre de 1522 .

${ }^{16} \mathrm{~J}$. Menéndez Pidal, art. cit., p. 189, nota 2.

17 Véase D. PAMP, "Introducción", a la Crónica burlesca..., p. 47.

18 Crónica burlesca.., pp. 172 y 174 . Esta enfática villa de Navarredonda no era más que un lugarejo, hoy inexistente, muy cercano a Béjar, en el que no había más de dos o tres molinos y una veintena de habitantes (véase JuAN Muñoz, "Datos para nuestra historia. Pago de un préstamo hecho al rey", Béjar en Madrid, núm. 1154, 16 de abril de 1924. 


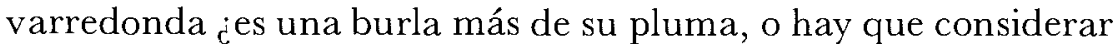
que se trata de un auténtico (aunque minúsculo) señorío? Sea como fuere, lo cierto es que el ya ex-bufón por esas fechas habla con cierto tono de propiedad sobre la villa de Navarredonda. Si en la corte era el más destacado de los bufones, fuera de ella es evidente que el escritor bejarano sustentaba su mayorazgo en algún recurso económico, que en sus insinuadas palabras bien pudiera ser alguna propiedad señorial o cuando menos agraria.

Alejado de la corte, don Francés conseguirá lo que con tanta insistencia había venido buscando dentro de ella: un oficio. Y un oficio ciertamente notorio. Como hemos dicho, regresó a Béjar, bajo el amparo de la mano protectora que siempre había estado tras de él: la del duque de Béjar. En septiembre de 1531, escasamente cinco meses antes de su muerte, don Francés de Zúñiga era nombrado Alguacil Mayor de la Villa de Béjar ${ }^{19}$. El largamente buscado oficio resultó ser un cargo público. De cómo llegó a tal oficio tenemos algunas pistas: su nombramiento aconteció pocas fechas después de la muerte de su protector, el duque. Un primer hecho evidente facilitó su acceso al cargo: la proximidad a la familia ducal. Pero otro más importante determinó que alcanzara tan preciada prenda: lo compró, como se compraron tantos otros cargos y prebendas en aquella España ${ }^{20}$.

Señalaba al principio de este trabajo unas palabras de A. Domínguez Ortiz en las que decía que "el favor, la habilidad y sobre todo la riqueza abrían un camino hacia arriba". La habilidad le fue innata a nuestro escritor; los favores no le faltaron (el último de los cuales pareció ser ese cargo al frente de lajusticia bejarana que le proveyó la duquesa); y la riqueza, si no tanta como suponía Monzón, sí desde luego mayor que la que el propio bufón argumentó a lo largo de todos sus escritos.

El mismo A. Domínguez Ortiz indica cómo fue "la diversidad de fortuna y profesiones la que introdujo dentro del cuerpo,

19 Archivo Histórico Nacional, Sección Osuna, leg. 219-612. Nada de extraño hay en esta consecución. Véase F. Márquez Villanueva, "Conversos y cargos concejiles en el siglo xv", RABM, 63 (1957), 503-540.

20 En junio de 1532 don Luis de Aguilar sucedía a don Francés en el cargo de Alguacil Mayor de Béjar. La duquesa doña Teresa de Zúñiga ordenaba una Provisión "para que dicho oficio de Alguacil no se diese a rentas según había andado en los años pasados y que ande en personas honradas e hidalgos: y que cada dos años la Justicia y Corregidor de Béjar nombre cuatro personas para que S. E. haga en una de ellas la elección de dicho oficio, lo cual quiere que sea perpetuamente'" (Archivo Histórico Nacional, Sección Osuna, leg. 218) 
teóricamente homogéneo de la nobleza, una jerarquía que venía a ser una concesión a los valores materiales" ${ }^{21}$. Así, divide a la nobleza en cuatro grupos que, de arriba a abajo, estarían formados por los Grandes, los títulos (condes y marqueses), los caballeros y los hidalgos. Nos interesan los dos últimos. De los hidalgos afirma Domínguez Ortiz que tal nombre, común en principio a todos los nobles, "acabó reservándose a los de escasa o nula fortuna"' ${ }^{22}$. No es el caso de don Francés, quien al final de su vida gozaba de la desahogada posición que hemos visto. De los caballeros, dice textualmente el insigne historiador: "Formaban una clase media urbana, con rentas suficientes para permitirles vivir noblemente, o sea, sin trabajar por sus manos; casi todos eran propietarios rurales, y algunos tenían el señorío de una villa o aldea, pero con frecuencia redondeaban sus ingresos con la posesión de oficios municipales"'23. No hay que argüir más para confirmar que al final de su vida don Francés de Zúñiga había alcanzado el estado social de caballero. No en vano buena parte de los manuscritos de la obra le dan el título de "Crónica del muy noble y esforzado caballero don Francés de Zúñiga', etc. ${ }^{24} \mathrm{Y}$ en algunos pasajes del Epistolario se otorga la misma condición. Así la carta que escribe a Leonor, hermana del emperador, tras su boda con Francisco I, hacia quien el bufón muestra su enojo: "Ni lo hizo como buen cavallero ni a ley de gentil hombre; y lo que más desto me pesa es lo que por las calles se dezía en viéndome: "Aquél es el caballero que syrue a la Reyna»"'25. Dando cuenta de la llegada a la corte de un criado de Charles de Lannoy, virrey de Nápoles, le dice a éste en una carta: "El cual, venido en España por vuestro amor, yo le haré que como me vea y me oiga, diga: Domine, nolite obdurare corda vestra, cuanto más que a un caballero semejante que yo, y de la parte donde vengo no le han de afrentar con el advertimiento de un loco" (60a, las cursivas en español son mías). De igual forma, en la carta para la emperatriz, don Francés se distancia de la clase de los villanos: "Los tres vasallos de la mi villa de Navarredonda son muertos de modorra, y no he podido acabar de tornarla a poblar. $Y$ porque no se perdiese mi ejercicio de arate $y$ cávate, y aunque otro bien no me quedase sino que de aquí adelante

21 Op. cit., p. 111.

22 Id.

23 Id.

24 Véase A. Morel-Fatlo y H. Leonardon, "La chronique scandaleuse d'un bouffon du temps de Charles-Quint', BHi, 11 (1909), 381-383.

${ }^{25} \mathrm{~J}$. Menéndez Pidal, art. cit., p. 75. 
quedase por villano, es bien para el día de hoy, y aún en el de mañana: podré decir que soy agrículo",26.

Qué duda cabe que esta licencia de llamarse caballero suena tan falsa en la pluma del bufón como cuando se concede títulos de conde, duque, infante o aun otros más ajenos a su persona. Nunca alcanzaría la nobleza de un título, pero desde luego sí estaba a su alcance la posición social del caballero, que aunque pueda parecernos una burla más de las suyas, bien pudo materializarse en la realidad. Esas accidentales y escasas referencias, su cargo al frente de la justicia bejarana, su posible posesión de la villa de Navarredonda, su mayorazgo, el uso del tratamiento de don, son un conjunto de datos que nos permitirían situar a don Francés entre la clase de los caballeros. Era un nuevo rico que había sabido subir por los resquicios que el sistema jerárquico de la sociedad había dejado abiertos: de sastre a bufón, de bufón a caballero. Un desheredado del que se puede afirmar que supo triunfar y medrar.

\section{LA CRÓNICA COMO MOTIVO GURRICULAR}

Hemos dado un repaso a la biografía del bufón, con la intención de perfilar la silueta de un hombre que se constituye a sí mismo como un homo novus tras el objetivo de ascender a la clase pudiente: un converso, como tantos otros, que supo acomodarse a la nueva situación y llegar tan alto como pudo. Su actividad literaria presenta dos planos claramente separados en el significado y el propósito de su aventura. Por una parte, está marcada por la misma ambición curricular que el resto de las acciones que configuran su biografía. La Crónica es escrita para la ostentación de quien aspira a mejorar su persona; es un mérito más, que presenta ante quienes tienen que considerarle; un instrumento valioso, que si entonces no le elevó tanto como hubiese querido, luego fue, sin embargo, la piedra preciosa que le ha traído a la cumbre de la literatura bufonesca hispana. Fuera de este sello de intención funcional que impregna todo lo que hace don Francés, hay que considerar a la obra bajo el interés de un doble punto de vista: el hecho de que el autor sea un escritor converso y al mismo tiempo la peculiaridad de tratarse de un loco de corte.

Tipificando las partes de que habría de constar una carta, Antonio de Torquemada establecía en su Manual de escribientes las di-

26 Crónica burlesca..., p. 172 (el subrayado es mío). 
ferentes funciones y contenido del prólogo, proemio y principio $^{27}$ :

son entre sí diferentes, no según los autores alegados, sino conforme a la orden que en el romançe castellano tenemos de aplicar estos vocablos, y la diferençia que yo hallo que tienen es ésta: que el prólogo es el que se pone en prinçipio de alguna obra, endereçándolo o dirigiéndola a alguna persona, y el prohemio es el que se pone en el prinçipio del libro o tratado, declarando la materia o materias que en él se tratan y la yntençión del autor...

La Crónica de don Francés no lleva prólogo alguno pero sí un Proemio, que es una declaración de sus intenciones ${ }^{28}$. Deja entender en él cuáles han sido los impulsos que le han llevado a ejercer por libre el oficio de cronista: aunque oscuro y confuso, todo el Proemio es una constante referencia al vivir bajo distintas formulaciones.

Principia con un "Necesario y cosa razonable es a los hombres buscar maneras de vivir", que ya nos pone sobre la pista. $\mathrm{Y}$ para ilustrar esas maneras de vivir aduce tres ejemplos, cada uno de los cuales entraña una distinta interpretación del verbo vivir:

1. El ejemplo de los animales y aves que se criaban en tierras del conde de Oñate y que emigraban pocos días antes de que fueran a ser cazadas. En este caso la interpretación es, evidentemente, la de 'sobrevivir'.

2. El ejemplo de los perros de caza de don Pedro de Ayala, que se soltaban en cuanto olían las ollas de los vecinos de su amo, para satisfacer su hambre. Aquí la interpretación es la de 'subsistir', buscarse el alimento propiamente dicho. Aquí vivir es satisfacer el hambre, mientras que en el primer ejemplo no era el hambre lo que movía la escena reflejada sino la supervivencia: salvar el pellejo.

3. El ejemplo de don Pedro de Sotomayor, que "había muerto a su madre por comer, y pensándolo tener, por el mismo delito le fue quitado". Aunque el juego de palabras hace pensar en alguna suerte de canibalismo nobiliario, en realidad la alusión va encami-

27 Antonio de Torquemada, Manual de escribientes, eds. M. J. Canellada y A. Zamora Vicente, Real Academia Española, Madrid, 1970, p. 214 (el subrayado es mío).

${ }^{28}$ Crónica burlesca..., pp. 67-68. Todas las referencias remiten a esta edición. - Aunque la cronología interna de la obra se inicia en 1516, don Francés no comenzó a escribirla sino en enero de 1525. Concretamente este Proemio que la abre fue redactado en Toledo en una fecha que podríamos situar entre abril y diciembre de dicho año (véase mi tesis Don Francés de Zúñiga. Biografía..., pp. 50 ss.) 
nada al problema hereditario, muy de la época. Don Pedro de Sotomayor supuestamente no mata a su madre por comer, sino por 'heredar'.

Como vemos, estos ejemplos implican distintos conceptos del término vivir que cubren con su ambigüedad la frase que abría el Proemio. Sin embargo, a pesar de esa libre interpretación del verbo vivir, hay un vector común a los tres ejemplos y a todo el Proemio: el alimento, el comer, la subsistencia. Los tres ejemplos son movidos, en distinto grado, por el comer. Dicho vector se ve apoyado por una cuarta referencia en el mismo Proemio, cuando se dirige directamente al emperador y le dice que "menester es que los perros de Bambri, y aún el mismo Bambri, que parece hecho de cera de sellos de cartas o paño de grana vieja, sea alimentado". Y todo ello sucede por "los inconvenientes que del no tener se siguen". De todo esto don Francés llega a la conclusión de que "muchas cosas nos da Dios Nuestro Señor a entender para que vivamos o para que nos dejen las gentes vivir". Hay a lo largo de todo el Proemio, como se ve, un círculo de términos que giran en la órbita de una misma idea: no tener, vivir, comer, etc.

Para Diane Pamp “don Francés no manifiesta otro propósito para escribir su Crónica que la necesidad de comer, sencilla y aplastante". Añade después que la obra "no es una crónica del hambre, sino una obra escrita (según el autor) por hambre"'. Dando a entender que el hambre ha llevado al bufón a las letras, apostilla Pamp que ésa es la forma que encuentra para crear una distancia prudente entre él y sus lectores cortesanos. Llega así a la conclusión de que "si bien matar el hambre es el propósito declarado de la obra del bufón, acaso el propósito no declarado ni declarable es el de crear una prudente y aconsejable distancia entre su mundo de converso y bufón, y el mundo de la España imperial'" 29 .

La lectura del Proemio me hace disentir de la opinión de Pamp respecto a la intención literaria de don Francés. El propósito declarado no es el hambre sino el por tres veces allí mencionado vivir: de vivir".

"Necesario y cosa razonable es a los hombres buscar maneras

"Sócrates escribía al conde don Fernando a la Coruña, diciéndole que no se maravillase de las animalías hacer esto, que escripto está: por vivir..."

29 "Introducción" a la Crónica burlesca..., pp. 49 ss. 
"Así que muchas cosas nos da Dios Nuestro Señor a entender para que vivamos o para que nos dejen las gentes vivir".

Creo que esta última cita es esencial para entender cuál es el propósito de don Francés. No es el hambre, sino las distintas formas que los hombres y los animales tienen de "buscar maneras de vivir". Y estas maneras de vivir las ejemplifica en la forma más básica y elemental de todas ellas: en el comer. No en el hambre, sino en el comer. Los animales y aves que habitan las tierras del conde de Oñate no emigran del lugar por comer, sino por no ser comidas, es decir, por vivir. Sí es el hambre, en cambio, lo que mueve a los perros de don Pedro de Ayala a soltarse e ir a satisfacerla en las ollas de sus vecinos. Pero en el tercer episodio, don Pedro de Sotomayor no es movido por el hambre física sino por el hambre de herencia: tener.

Este propósito declarado de que cada cual se las apaña de la mejor manera que puede para vivir, o para seguir viviendo, se enlaza muy directamente con el verdadero motivo por el cual don Francés se aventura en la empresa de escribir una crónica.

Hacia la fecha en que escribe el Proemio y gran parte de la obra (1525-1526), don Francés no tiene necesidad perentoria de crear distancia entre su mundo de converso y el de los cristianos viejos. Verdad es que como converso hay que intuir en él cierta dosis de precaución, pero desde luego su agresiva lengua no parece demostrar tal prudencia. Más que distanciarse, se diría que lo que busca es un cuerpo a cuerpo con aquellos cortesanos a los que con tino certero ridiculiza. Bien se podría decir que el bufón medía mal las fuerzas en ese choque, como lo demostraría su triste final. Pero no es un problema de proporción de fuerzas entre él y los cortesanos, a todas luces desigual, como sin duda lo sabía. don Francés. El distanciamiento estaba establecido de antemano por los principios estructurales de aquella sociedad, y no por ser converso sino bufón. Quien escribe la Crónica es un loco de corte, un ser que está fuera de la jerarquía por la propia condición del oficio. No hay mayor distancia que la del que está enfrente y es tratado como enemigo. El bufón, por la función de su oficio, es enemigo de los cortesanos, con quienes ha de estar en pugna permanente. La inteligencia de don Francés está en aviso de esa desigual lucha, a la que le obliga el oficio. ¿Qué otro sentido que huir de esa lucha tiene el que don Francés ande buscando mejor acomodo social que el de la bufonería? No le gusta el papel que le toca representar porque no es, ciertamente, el más grato. El hambre no es excusa, ni el distanciamiento prudente motivo en 
la Crónica. Su propósito se adentra mucho en las aspiraciones que sólo podía tener alguien con las espaldas bien limpias: medrar y alcanzar su dignificación como persona.

En la última carta del Epistolario, dirigida al emperador y escrita en Béjar hacia febrero o marzo de 1527 (poco tiempo después de que la Crónica, en versión incompleta, llegase a las manos de los cortesanos), don Francés declara, refiriéndose a la obra, que ya llevaba el Proemio escrito (61b, las cursivas son mías):

Si pensara, señor Emperador, que tan mal me había de suceder, y que tan poco habia de medrar, y que mis amigos había de perder, y tantos enemigos cobrar, y tantas sobarbadas llevar por una santiguada; y por la merced de los hijos de doña Sancha, que mal amenazado me han, que ni auctor me hiciera mi coronista me llamara. Mas no me maravilla, que negocio es muy usado que quien mucho habla su pago lleva y muy poco medra, digo de riquezas y bienes comunes; porque de palos y pescozones, en su mano es dallos, y mi trabajoso cuerpo recibillos.

Creo que queda claro, en sus propias palabras, cuál fue el no declarado motivo que llevó a don Francés a escribir la Crónica: medrar. Hemos visto que toda su vida fue una continua lucha por el ascenso social, por la superación de la adversa fortuna de sus ínfimos orígenes. La Crónica no pretendía otra cosa que ser un argumento más, un instrumento que bien manejado le ayudaría, visto desde el sentido más material, a medrar.

No deja de ser cierto que la carta mencionada se ve toda cruzada de arriba a abajo de referencias al hambre, al hambre que supuestamente pasa don Francés. Pero creo que tales referencias llevan humor: exagera su propia necesidad, marca de forma deliberada y bufonesca el extremo al que ha llegado su necesidad alimenticia; todo, por supuesto, es una superchería regocijante. Exagera hasta el punto de decir que el hambre le tiene "flaco y trasijado", pero más adelante en la misma carta dice: "No permitáis, Señor, mi alma llevar a cargo, ni que salga de mis carnes de hambre; porque solo el cuerpo no le pueden llevar treinta acémilas de las más señaladas de esta corte". Muy naco, pues, no debía estar. Por otras referencias de la Crónica sabemos de su obesidad; no era tanta el hambre que pasaba.

En el Proemio habia hecho don Francés referencia a la necesidad de que los perros de Dambaifueran alimentados. En la car- 
ta al emperador que comentamos vuelve a hacerse eco de ellos, pero añade aquí cosas muy sustanciales ${ }^{30}$ :

...de dar gritos sin que me oya vuestra majestad estoy ronco. Por amor de quien sois, sea yo oído, y en oyéndome, sea luego en bienes como los perros de Bauvri aprovechado, cuando se hartaban por la necesidad que tenían de las ollas de sus vecinos, que yo me contentaré con dos mill ducados de pensión sobre el arzobispado de Sevilla, aunque al dicho señor arzobispo le pese de me los dar, que ya conozco de mí no se me dará nada de los recibir. Porque la tal pensión me podrá sacar de lacería, y mi persona y casa tener autoridad..

Tanto los perros de Bambri como don Francés, tienen una necesidad, pero una necesidad distinta en cada caso: si para los perros de Bambri es la de satisfacer el hambre, y para ello pide el bufón al emperador en el Proemio que sean alimentados, en su propio caso la necesidad es de mayor alcance: unas rentas pide al emperador que le permitan vivir y "tener autoridad".

Todo gira en la misma órbita del Proemio: medrar, bienes, tener autoridad... Don Francés no busca sino honra y ascenso social. El hambre no es más que la argucia humorística bajo la que se esconde esa intención más profunda, que es medrar. La Crónica encaja así como una pieza más en la carrera que lleva a don Francés de la nada a la fortuna.

\section{LA CRÓNICA COMO REFLEJO DE LA BÚSQUEDA DE LA DIGNIDAD HUMANA}

La marginalidad de don Francés dentro de la sociedad que le toca vivir se produce por partida doble: converso y loco de corte. Vive dentro de un sistema social sin formar parte de él completamente. Su origen y su oficio son dos factores que condicionan no sólo su vida sino también el sentido de su obra. El primero de estos factores, la cuestión de la sangre, comprueba cómo desde este perfil de su personalidad la figura de nuestro escritor se enlaza, literaria y vitalmente, con un don Francés que busca, en medio de una sociedad hostil, un papel honroso, una dignificación de su persona, tener autoridad.

No vamos a entrar en consideraciones de detalle respecto al problema de ser converso, pero sí vamos a señalar determinados

30 Aquí don Francés confunde a los perros de Bambri o Bauvri (Adriano de Croy, señor de Beurren) con los de don Pedro de Ayala, a los que había adjudicado esta facecia en el Proemio (los subrayados del texto son míos). 
hechos que permitan un acercamiento a la personalidad literaria de don Francés. Ya señaló J. Caro Baroja la imposibilidad de querer ver en los judíos rasgos homogéneos que los caractericen en bloque $^{31}$. Valga su aserción para los conversos, que se presentan en muchos y lógicos aspectos como continuadores de aquéllos. Así, por ejemplo, en lo referente a las profesiones que en gran medida los "cristianos nuevos" mantienen de sus antepasados: mercaderes, arrendadores, alcabaleros, usureros, médicos, sastres, zapateros, etc. A principios del siglo XVI, los conversos copaban cargos como administradores y secretarios de la aristocracia. Y los hubo, como don Francés, que intentaron la aventura palaciega. Lo que no se encontrará entre ellos es el aventurero, el soldado o el marino, el pastor o el agricultor, que, aunque los hubo, eran oficios que en general quedaban lejos de su ánimo ${ }^{32}$. El pragmatismo del converso le empuja hacia los oficios y los hábitos de la clase media urbana, en buena parte configurada por ellos ${ }^{33}$.

La presión a que están sometidos por el grupo social dominante, el de los cristianos viejos, que proyecta sobre ellos sus culpas y responsabilidades y por el cual son zaheridos, genera una feroz resistencia ante el agresor o bien la búsqueda del camino para escapar a esa presión, mediante la asimilación. Dentro de la clase media urbana que acoge al converso, éste utiliza los medios que están a su disposición para diluirse y evitar la humillación de los cristianos viejos. El humorismo es uno de esos medios: adherirse a las burlas de la masa cristiana vieja, que representa tanto una adulación como una forma de defensa frente a esta masa.

En un intento de establecer una tipología de caracteres conversos, J. Caro Baroja presenta a don Francés de Zúñiga como ejemplo típico del converso que se burla de su propia condición $^{34}$. La mayoría de los escritores con verdaderos o supuestos orígenes conversos, se empeñaban en ocultar la mácula ${ }^{35}$. Sin embargo, don Francés, como Antón de Montoro y otros, adopta una actitud de abierto reconocimiento. Comenzando por sí mismo, se presta a un juego de culpas en el que, con intención, acaba saloicando a los que se creen a salvo, esos cortesanos vanidosos que presentan las mismas imperfecciones que el bufón. Si don Francés se ríe de sí mismo y de los que son como

31 J. Garo Baroja, op. cit., t. 3, p. 285.

32 Ibid., t. 2, pp. 15 ss; A. Domínguez Ortiz, Los judeoconversos en España y América, Istmo, Madrid, 1971, p. 21.

33 A. Domínguez Ortiz, El antiguo régimen..., p. 22.

34 J. Caro Baroja, op. cit., t. 1, pp. 302 ss.

35 A. Domínguez Ortiz, Los judeoconversos..., p. 161. 
él - conversos en busca de una paz digna dentro del orden social en el que conviven-, esa risa se hace extensiva a quienes se creen al margen de ella, es una forma de demostrar su cualificación a quienes no se la suponen.

El humorismo con que encara la existencia nuestro bufón es un medio legítimo y lúdico de confrontar su perfección ética, que a nadie engaña, con la mediocridad de tanto noble de conducta ambigua. Contra el medio vil que oprime su dignidad, don Francés arroja la red de la verdad, la cruel verdad que deja al descubierto las miserias de quienes se escondían en las apariencias. De la misma humillación a que se le somete saca el orgullo que, ingenioso y mortífero, castiga a los humilladores.

El colectivo converso formaba una minoría culta en la que existía un alto índice de científicos y literatos en proporción con su volumen numérico ${ }^{36}$. De la misma forma que entre ellos resultaba fácil encontrar en la economía al nuevo rico, era también fácil hallarlo en la cultura. La vida de don Francés fue la de un nuevo rico que parte del oficio de sastre para acabar en los linderos de la nobleza. Ya quedó apuntada la utilización material de la Crónica como arma en ese ascenso. Enlacemos ahora con lo que aquí hemos venido señalando respecto a las virtudes intelectuales de su linaje.

Sin desdeñar la suerte y el favoritismo, cabe reconocer en los entresijos de la Crónica la culminación de un proceso que don Francés supo utilizar, como fruto de su valía, y como ejercicio de acoso y derribo de la falsedad cortesana, en un cuerpo a cuerpo cuyo peligro conocían tanto el bufón como los desenmascarados cortesanos. Aquellos aristócratas no pudieron soportar la dureza de aquel sastre que vino a perturbar sus conciencias con el acoso de la verdad. Don Francés, que con sano humor hacía burla de sus propias miserias, comprendió que no podía ejercer la misma crítica con el mundo cortesano y quiso retirarse a tiempo del campo de batalla. No lo pudo hacer, como ahora mismo veremos, porque las funciones propias del bufón se lo impedían. Buscaba, pues, don Francés anular el estigma de su condición de converso por medio de la integración a aquel peldaño de la escala social que le permitiera escapar de la humillación del linaje y encontrar la dignificación personal.

Esta búsqueda, problema común al subgrupo intelectual converso, lleva a don Francés al oficio de bufón o loco de corte. O, más que oficio, digamos a la función de loco de corte, puesto que

36 Ibid., p. 159. 
su posición, más que un trabajo, representa un papel específico con unas encomiendas particulares y concretas. En un excelente estudio sobre el tema del loco ${ }^{37}$, C. Zijderveld estableció las diferencias entre el loco natural y el loco artificial. De este último apunta: "Ther played at being foolish, often with much wit and ingenuity. The role of fool was played by them in order to make a relatively decent living" 38 . Hacer el papel del loco fue una forma de buscarse la vida que a partir del siglo XV comienza a transformarse y a perder su lastre medieval. Fundamentalmente, lo que ocurrió, señala Zijderveld, fue un desplazamiento del loco desde la periferia de la sociedad cortesana hasta su centro, elevándose a la cúspide del poder, en un proceso de naturaleza estructural que lo situó en la misma isla de poder a la que es abocado el monarca absolutista: el bufón está más cerca del rey que ningún otro cortesano.

En ese proceso de recolocación, el papel del loco adquiere ciertos grados de influencia y poder que antes no tenía, al tiempo que varían sus funciones. Si decrece la de entretenimiento (que, por supuesto, sigue siendo fundamental), en cambio atrae otras que llenan vacíos estructurales en torno al rey: se convierte en su mejor y más leal amigo, en canal de información, espía o propagandista, como revela Zijderveld. Con todo ello, el papel del bufón no pierde la marginalidad que le caracteriza, puesto que sigue siendo un ser aislado (tanto como el propio rey) dentro de la cortesanía y que, por su poder, se sitúa frente a los propios cortesanos ${ }^{39}$.

En uno de los pocos caminos que le deja abiertos aquella sociedad hostil, don Francés alcanza, buscando vida, esa cúspide solitaria representando el papel del loco de corte. Un papel digno y honroso en su contexto: su poder le sitúa a la misma altura superior que la de sus compañeros cortesanos. Un poder basado en una proximidad a Carlos $V$ de la que no disfrutaban muchos nobles. Esa situación privilegiada (en la que no deja de ser instrumento en las manos del monarca) es la que le permite afirmar su inteligencia y establecer un ajuste de cuentas mediante el insulto de la verdad, privilegio tradicional que le era concedido al $10 \mathrm{lo}^{40}$.

Don Francés puede decir a viva voz lo que los demás tratan

37 G. ZijDerveld, Reality in a looking-glass: Rationality through an Analysis of Traditional Folly, Routledge \& Kegan-Paul, Boston, 1982, pp. 92-130.

38 Ibid., p. 92.

39 Ibid., pp. $115-122$ y $113-115$.

${ }^{40}$ Cf. R. KLEIN, "Un aspect de l'herméneutique à l'âge de l'humanisme classique. Le thème du fou et l'ironie humaniste", $A r F, 3$ (1963), 11-25. 
de ocultar. Y la verdad que el bufón bejarano proclama no es ingenua e inconsciente: entre las obligaciones de los de su gremio está la de tomar nota de los gustos e ideas de su amo, de qué cortesanos están en alza y cuáles en baja, de todo lo que ocurría fuera de lo ordinario... el bufón tenía que hacer el registro de todo ello y actuar en consecuencia ${ }^{41}$. La pulcritud moral que representa el privilegio de la verdad era algo que todos los que tenían algo que ocultar temían. En la Crónica don Francés no hace otra cosa que dejar en entredicho la conducta de la corte. No es de extrañar que más de uno en ella quisiera comprar su silencio con regalos más o menos oportunos.

Si don Francés alcanza una relativa dignitas hominis en su posición cortesana de bufón, también es cierto que no se encuentra cómodo en tal posición. El enfrentamiento permanente que sostiene con los cortesanos le hace aparecer como enemigo a batir. Si es una amenaza constante en la corte, también él está amenazado de volverse a ver reducido a cero. El mismo oficio que le da la dignidad la pone en peligro. Durante los escasos siete años que pasa al servicio del emperador, sabemos de varios momentos de crisis en los que el bufón permanece alejado de la corte.

Una primera vez a principios de 1524, en la que por razones desconocidas se ausenta durante tres meses, ausencia de la que en carta para el marqués de Pescara le afirma que "si el Emperador por mí no enviara, tarde volviera" (56b). Una segunda ocasión se produce en los primeros meses de 1527 en que vuelve a abandonar la corte tras la fulminante salida pública de su Crónica, que le trae amenazas y palos, y que lo mueve a decirle al propio rey que "ternía por mejor estarme yo en mi casa con mi mujer e hijos, descansando como otros hacen..."' $(61 b)$. La última y definitiva crisis se produce en enero de 1529 y es bien conocida: una broma mal medida delante del emperador le hace perder su favor y se retira de la corte para no volver a ella en los pocos años de vida que le quedaban ${ }^{42}$.

Es evidente que aquel constante juego de alumbrar sombras en las actitudes de los demás no favorecía nada la aspiración de don Francés de encontrar sitio donde poner a descansar su honra. De ahí que, como ya indicáramos anteriormente, su desasosiego le hiciera solicitar al emperador un medio de vida menos expuesto que el de bufón. Lo encontró al final de su vida en Béjar, lejos de la corte y de su amo. Los temores de don Francés

41 G. Zijderveld, op. cit., p. 106.

42 Véase J. Menéndez Pidal, art. cit., p. 196. 
por la peligrosidad de su oficio no eran vanos. Recordemos aquel pasaje en el que el bufón no se atrevió a apodar a ciertos caballeros extremeños "porque fue informado que daban espaldarazos que quitaban la habla"'43. Y recordemos que, aparecida la Crónica incompleta en 1527, el pobre bufón había de comunicarle al emperador que "el duque de Béjar no me mira, aunque pase junto a él, y el Condestable me guiña, el marqués de Cenete me amenaza, musior de Laxao me las jura, y Sancho Bravo me las pega" (62a). No son las únicas referencias del bufón a la dificultad de su cometido. A la postre, aquel ejercicio de mostrar la realidad acabó costándole la vida.

En definitiva, la Crónica de don Francés representa en su biografía un elemento de ostentación curricular de quien, siendo converso, aspira al éxito en la carrera del medro. Y en ella se trasluce esa pugna de manifestar su inteligencia y su dignidad personal, en medio ( $y$ a costa) de una sociedad reacia a permitir y reconocer la valía de quien ejercita la moral como marco de su conducta.

José Antonio Sánchez Paso 